\title{
The Discussion on Question of Professional Degree Graduate Education
}

\author{
Jingbo XU, Hongtao YU \\ National Digital Switching System Engineering and Technological Research Center, Zhengzhou, Henan, \\ China
}

\begin{abstract}
Since 1991, after 20 years of efforts and the construction of professional degree graduate education, Professional degree graduate education is developing rapidly in our country, with China characteristics of the professional degree education system was established, it has trained a large number of high-level, applied talents for the socialist modernization. This paper discusses the characteristics of professional graduate education present situation, to enhance the competitiveness of graduate students and the social recognition to improve discussed.
\end{abstract}

KEYWORD: Professional degree graduate; talent; competitiveness; recognition

\section{INTRODUCTION}

Professional degree, is compared to the academic degree in terms of degree type, its purpose is to train with a solid theoretical foundation, and adapt to a particular industry or occupation need practical work applied high level talents. Professional degree is guided by professional practice, pay attention to practice and application, in the cultivation of professional and specialized technology by high level talent formal training, high level. The prominent characteristic of professional degree education is the academic type closely integrated with the occupation, to obtain a professional degree of people, mainly engaged in has the obvious occupation background work.

At present, with the further establish and improve the system, mechanism, professional degree graduate education is bound to usher in a rapid development of the spring[1], will also play a positive role in promoting a more and more important in the state construction undertakings in the process.

\section{A CORRECT UNDERSTANDING OF THE STATUS QUO OF PROFESSIONAL DEGREE GRADUATE EDUCATION IN CHINA}

First of all, our professional degree graduate education has just started, the cultivation of small scale, accounted for only 1/10 of master's degrees[2], and the existence of talent cultivation target single, poor adaptability, and social needs coincide degree is not high, the impact on the sustainable development of postgraduate education. and as soon as possible to find the problem rapid, definitely be torsion is simply. From a focus on Graduate Employment whereabouts, the training of applied talents are in urgent need of economic and social development to start, gradually realize the structure optimization of the structure. The enrollment of graduate education, classification of clear training objectives, to promote the effective connection between personnel training and social needs.

Secondly, professional tutor of master degree level is low, less experience, academic structure is not reasonable. Less than $10 \%$ of ordinary colleges full-time teachers in our country have a $\mathrm{PhD}$, American University teachers have a doctorate ratio of more than $90 \%$. American first-class universities attach great importance to teachers "hybridization", many graduates have at other universities, teaching research institutions or business experience before returning to his alma mater. And the degree of China's University Teachers inbreeding was significantly higher than other countries, studies have shown that the average high of nearly 5 times. "Eco academic system formed inbreeding coefficient" has the homogeneity[3], is not conducive to academic innovation, but also easy to cause degeneration of the University academic.

Once again, the professional degree graduate education evaluation and evaluation system of heavy light development needs to be improved. Due to the following special low threshold, the source of 
students and the knowledge base must have the gap with the doctrine, but except for a small portion outside the school, most schools designed following and theory of cultivation mode evaluation system, that is to say the characteristics of professional degree graduate students did not come out, so the socalled appraisal characteristics more applicationoriented basically did not reflect well the. Foreign university in the professional degree graduate education re evaluation of professional skills development focus on the following special evaluation process, Harvard University, Yale University and other schools have set up the system according to the different professional degree graduate education evaluation of the development of light and heavy project evaluation mechanism. Our evaluation system too much emphasis on the theory of evaluation and degree level, lack of development indicators, the weakening of the professional degree graduate education development in the future. At the same time, single evaluation standard, match different subject type feature evaluation system has not been established.

\section{TO IMPROVE THE PROFESSIONAL DEGREE GRADUATE COMPETITIVENESS}

Professional degree graduate ability and enhance the competitiveness of science and technology innovation capacity is the source of knowledge. So far the impact of human life style of major scientific and technological achievements in $70 \%$ was born in research universities, professional degree of growing up in such an environment of scientific research of birth than academic masters practice course, early contact with professional field project and scientific research, with more practice time and the opportunity to exercise the. On the other hand, professional degree graduate students than general professional degree graduate, therefore, their theoretical foundation of knowledge and skills in practice to strengthen and cultivate. And sublimation in practice theory is solid and firm, so, jointly improve professional degree graduate level of theory, practice ability, competitiveness is not unattainable.

\section{ENHANCE THE PROFESSIONAL DEGREE GRADUATE DEGREE OF SOCIAL RECOGNITION}

Because the training purpose and different tendencies, two master degree exam the final recognition also has some differences. Ordinary master (including academic master and full-time professional degree graduate) higher than that of in- service professional degree graduate degree recognized in academic recognition.

Although many college full-time professional degree graduate faculty input, set up scholarships, training mode, gradually perfect, but relatively wellknown academic master, professional degree graduate or some weak, is cold is normal. In the professional degree of development of the students how to steady the market, being recognized?

Because of on-the-job professional degree students recruitment background itself is pay attention to declare the work background and practical experience. Although there was still no with academic than, the development prospect is good. In recent years, with the increasing number of candidates for the master species, increased year after year, so the sentiment driven market effect, the recognition and job status is also increasing year by year.

\section{SUMMARY}

The academic development is an infinite process, construction of higher education is an asymptotic process. The development of the post-graduate education cannot do without some form of education, training, but more attention is boosting demand and education combined with the tacit understanding. At present, the professional degree education in our country is in the development opportunity[4], we must seize the opportunity, take measures, and actively promote the rapid development of professional degree education. Due to China's rapid economic and social development, economic structural adjustment and transformation is in the period of occupation differentiation, more and more fine, more and more types of occupation, the technical content is higher and higher, the society in the management, engineering, architecture, law, finance, education, agriculture and other professional areas of demand for talents is more and more strong, professional degree education has occupation, complex features, applications are gradually recognized by most people, its appeal will continue to increase. Therefore, the professional degree graduate cultivation scale must be correspondingly larger development.

\section{REFERENCES}

[1] Jianjun Tan, Chunhua Li, and Shuicai Wu, "The full-time professional degree graduate training mission and responsibility of instructors in the China Power Education", vol. 23, pp. 47-48, July 2011.

[2] Ningwei Zhao "Full time professional master degree education know again" Chinese graduate student, vol. 6, pp. 89-90, August 2011. 
[3] Yuying Xiong, "A survey and analysis of professional master's students full-time quantity factors," Chinese graduate student, vol. 6, pp. 39-40, August 2011
[4] Guoyu Liu, "Discussion on basic characteristics of professional degree graduate education and its realization," China Higher Education Research,, vol.11, pp. 31-32, 2005 